\title{
DAMPAK PERUBAHAN IKLIM TERHADAP HASIL TANAMAN PADI DI KAWASAN DANAU SINGKARAK
}

\author{
Yummama Karmaita ${ }^{1}$ \\ Email Author: yummakarmai@yahoo.co.id
}

\begin{abstract}
ABSTRAK
Penelitian ini bertujuan untuk: (i) melihat hasil beberapa genotipe tanaman padi sawah yang mengalami cekaman kekeringan, (ii) untuk mendapatkan jenis genotipe padi sawah yang adaptif terhadap cekaman kekeringan. Percobaan ini dilakukan pada lahan sawah tadah hujan nagari Simawang, kecamatan Rambatan, kabupaten Tanah Datar dan Laboratorium Fakultas Pertanian Universitas Andalas Padang. Analisis data dilakkan dengan menggunakan metode Rancangan Acak kelompok (RAK) dengan menggunakan 7 genotipe padi, 6 genotipe padi sawah dan 1 genotipe padi gogo sebagai pembanding. Jika $F$ hitung lebih besar dari $\mathrm{F}$ tabel 5\% maka dilakukan uji lanjut dengan menggunakan uji BNJ (Beda Nyata Jujur) pada taraf nyata 5\%. Semua genotipe padi sawah lokal yang diuji memperlihatkan hasil yang cukup baik pada lahan sawah yang mengalami cekaman kekeringan, dan semua genotipe menunjukkan pengaruh yang berbeda nyata terhadap jumlah anakan produktif, panjang malai, jumlah gabah per malai, persentase gabah bernas per malai.
\end{abstract}

Kata kunci : Perubahan iklim , Padi, Kawasan Danau Singkarak

\begin{abstract}
This study aims to: (a) see the results of several genotypes of rice crops grown on paddy fields with drought stress, (b) to obtain the type of paddy rice genotype in droughtaffected paddy fields. This research was conducted in Simusan rice field, Rambatan sub-district, Tanah Datar district and Laboratory of Agriculture Faculty, Andalas University, West Sumatra. This research used Randomized Block Design (RBD) method using 7 rice genotypes, 6 rice field genotypes and 1 genotype of upland rice as a comparison. If $\mathrm{F}$ value is greater than $\mathrm{F}$ table $5 \%$ it needs to be continued using Tukey test at $5 \%$. The results revealed that in general, all the rice genotypes tested in showed good results on paddy fields that suffered drought stress, where all these genotypes showed a significantly different effect on the number of productive tillers, panicle length, number of grains per panicle, the percentage of unpaid grain per panicle.
\end{abstract}

Keywords: Climate exchange, rice, Singkarak Lake area.

1 


\section{PENDAHULUAN}

Perubahan iklim merupakan
fenomena global yang merupakan
tantangan serius pada pengembangan di
bidang pertanian pada saat ini dan masa
yang akan datang. Rusaknya instalasi
pengairan menimbulkan resiko kekeringan
terutama pada lahan gogo dan sawah tadah
hujan. Perubahan polah curah hujan,
kenaikan muka air laut, dan suhu udara,
serta peningkatan kejadian iklim ekstrim
berupa banjir dan kekeringan merupakan
beberapa dampak serius perubahan iklim
yang dihadapi petani.

Perubahan iklim sebagai fenomena alam ini yang melanda dewasa ini mulai dirasakan dampaknya di daerah nagari Simawang yang berada di sebelah timur danau Singkarak Sumatera Barat. Hal ini berdampak pada sukarnya petani dalam memprediksi pola curah hujan, sehingga berdampak pada sektor partanian, terutama terhadap penanaman padi. Lahan sawah tadah hujan seluas 238 ha dan sekitar 50 ha ditemukan lahan bekas sawah yang saat ini sama sekali tidak lagi produktif, disebabkan lahan tersebut mengalami kekeringan dikarenakan kurangnya pasokan air air irigasi maupun air hujan, sehingga akhirnya lahan tersebut menjadi lahan tidur dan hanya digunakan sebagai lahan pengembalaan ternak.

Lahan sawah seluas sekitar 50 ha yang berada di Jorong Darek dan Jorong Koto Gadang, yang oleh masyarakat disebut sebagai hamparan sawah ketaping yang dimiliki oleh sekitar 75 kepala keluarga. Selain dari hujan, sawah ini juga memperoleh pengairan dari Talago Janik yang berjarak $500 \mathrm{~m}$ dari hamparan tersebut dan satu sumber air yang berada di hamparan. Dari hasil survei diketahui bahwa rata-rata kepemilikan lahan per rumah tangga di Hamparan Sawah Ketaping adalah sekitar 0,4 ha. Sebelum musim kekeringan, hampir semua petani dapat mengusahakan lahan sawah mereka dua kali setahun yang umumnya selama musim hujan dari Oktober/Nopember sampai April/Mai. Salah satu informasi kunci menyatakan bahwa ketika dia pindah ke Jorong Koto Gadang karena menikah pada tahun 1998, dia masih bisa bertanam padi dua kali musim tanam dengan menggunakan mata air yang berada di hamparan tersebut, tapi satu tahun setelah itu mata air tesebut jadi tidak stabil dan dia tidak mampu lagi membajak sawahnya (Febriamansyah et al., 2012). Kondisi sawah yang seperti ini sangat mengkhawatirkan dan dapat menjadi ancaman terhadap hasil produksi padi, sementara kebutuhan pangan terhadap beras semakin meningkat seiring dengan meningkatnya jumlah penduduk.

Genotipe padi yang adaptif pada kondisi cekaman kekeringan menjadi salah satu komponen teknologi yang penting untuk mengantisipasi dampak perubahan iklim khususnya lahan-lahan sawah yang rawan cekaman kekeringan. Tubur et al., (2012) menyatakan bahwa beberapa pengujian yang dilakukan untuk memperoleh genotipe tanamanpadi sawah atau gogo yang toleran kekeringan telah banyak dilakukan di dalam pot di rumah kaca ataupun pada skala laboratorium dengan menggunakan polyethylene glycol (PEG). PEG merupakan salah satu jenis senyawa osmotikum yang digunakan untuk mentsimulasi kondisi kekeringan, karena sifatnya dapat menghambat penyerapan air oleh sel atau jaringan tanaman. Namun pengujian di lapangan dengan kondisi sawah yang mengalami cekaman kekeringan belum banyak dilakukan. Oleh karena itu pengujian untuk mengetahui respon pertumbuhan dan kualitas hasil beberapa genotipe padi pada sawah yang mengalami cekaman kekeringan sangat penting dilakukan. 
Provinsi Sumatera Barat memiliki banyak sekali genotipe atau varietas padi lokal yang belum diketahui tingkat toleransinya terhadap kekeringan. Swasti, Syarif, Suliansyah dan Putri (2007) melalui kegiatan ekplorasi telah berhasil mengumpulkan sebanyak 182 genotipe padi lokal Sumatera Barat. Belum seluruh koleksi genotipe padi lokal tersebut diketahui toleran atau tidak terhadap cekaman kekeringan sehingga untuk itu diperlukan adanya penelitian dengan padi lokal Sumatera Barat.Penelitian ini bertujuan untuk melihat pertumbuhan dan hasil beberapa genotipe tanaman padi yang ditanam pada sawahyang mengalami cekaman kekeringan dan untuk mendapatkan jenis genotipe padiyang adaptif di lahan sawah yang mengalami cekaman kekeringan.

\section{BAHAN DAN METODA}

Penelitian ini telah dilaksanakan di lahan sawah tadah hujan nagari Simawang, Kecamatan Rambatan, Kabupaten Tanah Datar dan Laboratorium Fakultas Pertanian Universitas Andalas Padang.

Bahan genetik yang digunakan untuk penelitian ini adalah benih padi genotipe Saganggam Panuah, Caredek Putiah, Junjuang, Bakwan, Kuriak Kusuik, Limboto, Kuniang Aro. Pupuk kandang sapi 30 ton ha ${ }^{-1}$, pupuk Urea $(43 \%$ N) 200 $\mathrm{kg} \mathrm{ha}^{-1}, \mathrm{Sp}-36$ (36\% P2O5) $100 \mathrm{~kg} \mathrm{ha}^{-1}$, pupuk $\mathrm{KCl}(49,80 \% \mathrm{~K} 2 \mathrm{O}) 75 \mathrm{~kg} \mathrm{ha}^{-1}$, dan fungisida dengan merek dagang Fujiwan 400. Alat yang digunakan adalah cangkul, sabit, ember, karung, waring, tiang, meteran, timbangan analitik, kamera, label, tiang standar, papan triplek, oven, kertas amplop, gunting, dan alat-alat tulis.

Penelitian ini menggunakan Rancangan Acak Kelompok yang terdiri dari 7 perlakuan dan 3 kelompok. Ukuran plot percobaan adalah $3 \mathrm{~m}$ x $4 \mathrm{~m}$, jarak antar plot 0,5 $\mathrm{m}$ dan antar kelompok $1 \mathrm{~m}$. Perlakuan yang digunakan dalam penelitian ini adalah genotipe Saganggam Panuah (SP), junjuang (JJ), Caredek Putiah (CP), Kuniang Aro (KA), Bakwa (BK), Kuriak Kusuik (KK), dan Limboto (LB). Data variable pengamatan dianalisis dengan menggunakan metodestatistik (sidik ragam). Jika $\mathrm{F}$ hitung lebih besar dari $\mathrm{F}$ tabel 5\% maka dilakukan uji lanjut dengan menggunakan BNJ (beda nyata jujur) pada taraf a 5\%. Data yang tidak menyebar normal ditransformasi dahulu sebelum diolah.

Tanam pada umur bibit 15 hari setelah sebar (HSS), jumlah bibit 4 tanaman/lubang, dengan jarak tanam 25 $\mathrm{cm}$ x $25 \mathrm{~cm}$. Ukuran petak perlakuan 3 mx4 m sebanyak 21 ubinan. Pemberian pupuk Fosfat (P), Kalium (K) dan Nitrogen $(\mathrm{N})$ diberikan 2 kali yaitu pada saat tanaman sudah berumur 2 minggu setelah tanam (MST) dan saat tanaman berumur 6 MST, dengan dosis masingmasing pupuk urea (200 kg ha-1), $\mathrm{KCl}(75$ $\left.\mathrm{kg} \mathrm{ha}^{-1}\right)$, dan SP-36 (100kg ha-1).

Variabel pengamatan yang diamati adalah: jumlah anakan produktif, panjang malai, jumlah gabah per malai, persentase gabah bernas per malai dengan menggunakan rumus:

$\%$ Gabah Bernas $=\frac{\text { Jumlah gabah bernas }}{\text { Jumlah gabah pertanaman }} \times 100 \%$.

\section{PEMBAHASAN}

3.1. Jumlah Anakan Produktif

Berdasarkan sidik ragam pada taraf nyata $5 \%$ perlakuan beberapa genotipe padi sawah yang mengalami cekaman kekeringan berpengaruh nyata terhadap jumlah anakan produktif, panjang malai dan jumlah gabah per malai. Hal ini mengindikasikan bahwa terdapat perbedaan respon antara genotipe akibat cekaman kekeringan. Pengaruh cekaman kekeringan terhadap 
jumlah anakan produktif pada masingmasing genotipe padi tersaji pada Tabel 1.

Tabel 1. Pengaruh cekaman kekeringan terhadap jumlah anakan produktif.

\begin{tabular}{lc}
\hline \multicolumn{1}{c}{ Genotipe } & $\begin{array}{c}\text { Jumlah Anakan } \\
\text { Produktif }\end{array}$ \\
\hline Saganggam Panuah & $23,00 \mathrm{a}$ \\
\hline Junjuang & $20,95 \mathrm{ab}$ \\
\hline Caredek Putiah & $22,46 \mathrm{a}$ \\
\hline Kuniang Aro & $23,67 \mathrm{a}$ \\
\hline Bakwan & $22,19 \mathrm{a}$ \\
\hline Kuriak Kusuik & $19,51 \mathrm{ab}$ \\
\hline Limboto & $14,45 \mathrm{~b}$ \\
\hline KK $(\%)$ & 10,92 \\
\hline BNJ & 6,68
\end{tabular}

Angka-angka pada kolom yang sama diikuti oleh huruf kecil yang sama adalah berbeda tidak nyata menurut uji BNJ pada taraf nyata $5 \%$.

Berdasarkan Tabel 1 dapat dilihat bahwa berdasarkan uji lanjut BNJ pada taraf nyata 5\% genotipe Limboto menunjukkan jumlah anakan produktif yang berbeda nyata terhadap genotipe Saganggam Panuah, Caredek Putiah, Bakwan, dan Kuniang Aro tetapi genotipe Limboto berbeda tidak nyata terhadap genotipe Junjuang dan Kuriak Kusuik. Walaupun genotipe Limboto dengan genotipe Junjuang dan Kuriak Kusuik memiliki genetik yang berbeda, namun mekanismenya dalam menghadapi cekaman kekeringan relatif sama.

Air merupakan salah satu bahan baku dalam proses fotosintesis dimana air yang dibutuhkan lebih kurang 5\% dari jumlah air yang diserap oleh akar, sehingga proses metabolisme dapat berjalan dengan baik. Fotosintesis yang berlangsung dengan baik akan menghasilkan fotosintat yang cukup untuk dapat dialokasikan kepembentukan anakan produktif.

\subsection{Panjang Malai}

Berdasarkan sidik ragam pada taraf nyata $5 \%$ perlakuan beberapa genotipe padi sawah yang mengalami cekaman kekeringan berpengaruh nyata terhadap panjang malai. Pengaruh cekaman kekeringan terhadap panjang malai pada masing-masing genotipe padi tersaji pada Tabel 2 .

Tabel 2. Pengaruh cekaman kekeringan terhadap Panjang Malai.

\begin{tabular}{lc}
\hline \multicolumn{1}{c}{ Genotipe } & Panjang Malai \\
\hline Saganggam Panuah & $22,60 \mathrm{bc}$ \\
\hline Junjuang & $21,41 \mathrm{c}$ \\
\hline Caredek Putiah & $21,87 \mathrm{c}$ \\
\hline Kuniang Aro & $21,04 \mathrm{c}$ \\
\hline Bakwan & $22,37 \mathrm{bc}$ \\
\hline Kuriak Kusuik & $25,25 \mathrm{a}$ \\
\hline Limboto & $24,14 \mathrm{~b}$ \\
\hline KK $(\%)$ & 2,99 \\
\hline BNJ & 1,94 \\
\hline
\end{tabular}

Berdasarkan uji lanjut BNJ pada taraf nyata $5 \%$ untuk panjang malai memberikan hasil yang berbeda nyata antara genotipe Kuriak Kusuik dengan genotipe Saganggam Panuah, Junjuang, Caredek Putiah, Kuniang Aro, Bakwan, dan Limboto. Terjadinya perbedaan ini disebabkan bahwa genotipe Kuriak Kusuik memiliki umur tanaman yang lebih lama dibandingkan genotipe yang lain, namun denga genotipe Caredek putiah memiliki umur yang sama tetapi dalam proses memasuki fase reproduktif berbeda. Hal tersebut menyebabkan genotipe Kuriak Kusuik berada dalam kondisi cekaman kekeringan yang lebih lama, sehingga fotosintat dari proses fotosintesis yang disalurkan melalui daun ke malai hanya digunakan untuk pemanjangan malai. 
Munir (2009) menyatakan bahwa panjang malai dan jumlah gabah per malai sangat dipengaruhi oleh sifat genetik dan lingkungan tumbuhnya. Sifat genetik akan muncul melalui pertumbuhan organ apabila faktor lingkungan sesuai. Lebih lanjut Hayani et al., 1999 menjelaskan setiap varietas padi mempunyai ciri-ciri khas tersendiri dan tergantung pada sifat genetik yang dikandung masing-masing varietas serta kemampuan dan daya adaptasinya terhadap lingkungan tumbuh. Panjang malai yang panjang pada genotipe padi gogo, disebabkan relokasi cadangan karbohidrat yang sangat efektif pada padi gogo dibandingkan dengan genotipe padi sawah, pada kondisi cekaman kekeringan.

\subsection{Jumlah Gabah Per Malai}

Berdasarkan sidik ragam pada taraf nyata $5 \%$ perlakuan beberapa genotipe padi sawah yang mengalami cekaman kekeringan berpengaruh nyata terhadap jumlah gabah per malai. Pengaruh cekaman kekeringan terhadap jumlah gabah per malai pada masingmasing genotipe padi tersaji pada Tabel 3.

Tabel 3. Pengaruh cekaman kekeringan terhadap Jumlah Gabah Per Malai.

\begin{tabular}{lc}
\hline \multicolumn{1}{c}{ Genotipe } & $\begin{array}{c}\text { Jumlah Gabah Per } \\
\text { Malai }\end{array}$ \\
\hline Saganggam Panuah & $102,33 \mathrm{~b}$ \\
\hline Junjuang & $110,67 \mathrm{~b}$ \\
\hline Caredek Putiah & $121,09 \mathrm{~b}$ \\
\hline Kuniang Aro & $107,57 \mathrm{~b}$ \\
\hline Bakwan & $94,60 \mathrm{~b}$ \\
\hline Kuriak Kusuik & $121,25 \mathrm{ab}$ \\
\hline Limboto & $147,17 \mathrm{a}$ \\
\hline KK $(\%)$ & 10,24 \\
\hline BNJ & 33,61 \\
\hline
\end{tabular}

Dari Tabel 3 dapat dilihat bahwa jumlah gabah per malai genotipe Limboto berbeda nyata dengan genotipe Saganggam Panuah, Junjuang, Caredek Putiah, Kuniang Aro, dan Bakwan namun berbeda tidak nyata dengan genotipe Kuriak Kusuik. Hal ini disebabkan bahwa genotipe Limboto dan Kuriak kusuik memiliki panjag malai terpanjang diantara genotipe yang lain, ini berarti bahwa semakin panjang malai maka jumlah gabah yang terbentuk juga semakin banyak dan begitu juga sebaliknya. Semakin pendek malai maka jumlah gabah yang terbentuk juga semakin sedikit. Meskipun demikian bertolak belakang dengan genotipe Bakwan, dimana genotipe ini memiliki panjag malai terpanjang diantara genotipe Junjuang, Caredek Putiah, Dan Kuniang Aro namun genotipe Bakwan menghasilkan Jumlah gabah permalai paling sedikit. Hal ini disebabkan bahwa genotipe Bakwan pada saat tanaman berumur 7 MST terserang oleh penyakit Bals Daun sehingga pertumbuhannya terhambat salah satunya dalam proses fotosintesis sehingga fotosintat yang dihasilkan tidak mencukupi untuk pembentukkan gabah.

Tubur (2012) menyatakan bahwa kekeringan pada fase reproduktif menurunkan jumlah anakan produktif, persentase pembungaan dan berasosiasi negatif dengan hasil gabah, terutama dengan meningkatnya gabah hampa.

Selanjutnya tingginya jumlah gabah per malai yang dihasilkan, juga berhubungan dengan respon dan kemampuan genotipe yang tinggi dalam mengabsorpsi nutrient yang berada dalam tanah serta kemampuan memanfaatkan faktor lingkungan yang mempengaruhi pertumbuhan dan produktivitas tanaman seperti air, suhu, intensitas cahaya matahari, dan 
sebagainya. Perbedaan kemampuan tanaman ini akan ditunjukkan dalam bentuk pertumbuhan dan produktivitas yang lebih baik, termasuk jumlah gabah.

\subsection{Persentase Gabah Bernas Per Malai (\%)}

Berdasarkan sidik ragam pada taraf nyata $5 \%$ perlakuan beberapa genotipe padi sawah yang mengalami cekaman kekeringan berpengaruh nyata terhadap persentase gabah bernas per malai. Pengaruh cekaman kekeringan terhadap persentase gabah bernas per malai pada masing-masing genotipe padi tersaji pada Tabel 4.

Tabel 4. Pengaruh cekaman kekeringan terhadap persentase gabah bernas per malai.

\begin{tabular}{lc}
\hline \multicolumn{1}{c}{ Genotipe } & $\begin{array}{c}\text { Persentase Gabah } \\
\text { Bernas } \\
\text { Per Malai (\%) }\end{array}$ \\
\hline Saganggam Panuah & $89,46 \mathrm{a}$ \\
Junjuang & $82,07 \mathrm{ab}$ \\
Caredek Putiah & $67,83 \mathrm{bc}$ \\
Kuniang Aro & $79,73 \mathrm{abc}$ \\
Bakwan & $76,77 \mathrm{abc}$ \\
Kuriak Kusuik & $63,40 \mathrm{c}$ \\
Limboto & $89,20 \mathrm{a}$ \\
\hline KK (\%) & 7,68 \\
BNJ & 17,21 \\
\hline
\end{tabular}

Tabel 4 menunjukkan bahwa berdasarkan uji lanjut BNJ pada taraf nyata $5 \%$ pengaruh cekaman kekeringan terhadap persentase gabah bernas per malai genotipe Saganggam Panuah memberikan hasil yang berbeda nyata dengan genotipe Caredek Putiah dan Kuriak Kusuik. Hal ini disebabkan bahwa genotipe Sanganggam Panuah memiliki umur panen lebih cepat dari genotipe Kuriak Kusuik dan Caredek Putiah, sehingga genotipe Saganggam
Panuah mendapatkan periode cekaman kekeringan lebih pendek sedangkan kedua genotipe tersebut lebih lama. Sehingga genotipe Saganggam Panuah dalam proses pengisian biji tidak terganggu karena proses fotosintesis berjalan dengan lancar dan translokasi fotosintat yang dihasilkan juga berjalan dengan lancar ke biji sehingga genotipe ini memiliki persentase gabah bernas tertinggi dibandingkan Caredek Putian dan Kuriak Kusuik.

Ermawati (1996) menyatakan bahwa kekeringan yang terjadi selama masa reproduktif pada tanaman kedele menyebabkan translokasi fotosintat masuk ke dalam benih menjadi lambat, akibatnya terjadi penurunan bobot benih total dan jumlah polong bernas rendah. Kekurangan air selama masa pengisian polong pada tanaman kedele menurunkan hasil dengan kecilnya ukuran biji 8-20\%, dengan percepatan penuaan daun dan singkatnya periode pengisian polong. Kekurangan air juga sangat berpengaruh pada kemampuan tanaman dalam menyerap hara sehingga tanaman mengalami defisit hara. Absorbsi hara yang terhambat dapat mengakibatkan kadar $\mathrm{N}$ total tanaman dan laju pengambilan $\mathrm{N}$ persatuan bobot kering akar secara nyata berkurang dengan turunnya laju potensial osmotik larutan hara (Walangi, 1996).

\section{KESIMPULAN}

Berdasarkan hasil penelitian pengujian toleransi beberapa genotipe padi yang ditanam pada lahan sawah yang mengalami cekaman kekeringan dapat ditarik kesimpulan bahwa secara umum semua genotipe padi sawah yang diuji dalam penelitian ini memperlihatkan hasil yang cukup baik pada lahan sawah yang mengalami cekaman kekeringan. Dimana semua 
genotipe ini menunjukkan pengaruh yang berbeda nyata terhadap jumlah anakan produktif, panjang malai, jumlah gabah per malai, persentase gabah bernas per malai.

\section{UCAPAN TERIMAKASIH}

Ucapkan terima kasih penulis sampaikan kepada PEER USAID yang telah mendanai penelitian ini.

\section{DAFTAR PUSTAKA}

Ermawati, Kartika. 1996. Pengaruh Tekanan Kekeringan saat Fase Generatif dan Dosis Urea terhadap Proses Tanaman Kedelai. Jurnal Tropika No 2: 4143hal.

Febriamansyah, R., Refdinal, Marni, Y., Dan L. Hanum. 2012. The Climate Change and the Lost of primary Economic Source of Rainfed Paddy farmers: a Case Study from Nagari Simawang, West Sumatra, Indonesia.
Hayani, Slameto, dan Sopandi. 1999. Kajian dosis pupuk NPK pada beberapa varietas padi di Sidorahayu. Lampung Selatan. Dalam Prosiding Kongres Nasional VII HITI. Bandung. 236 hlm.

Munir, R dan Haryoko, W. 2009. Uji Adaptasi Beberapa Varietas Unggul Padi Sawah Pada Lahan Gambut. Jerami Volume 2 No. 3. ISSN 1979-0228.

Tubur, W. H., Chozin, M. A., Santosa, E dan A., Junaedi. 2012. Respon Agronomi Varietas Padi terhadap Periode Kekeringan pada Sistem Sawah. J. Agron. Indonesia 40 (3) : $167-17.75-86$.

Walangi, D. I. 1996. Pengaruh Stress Air dan Pemupukan Nitrogen Terhadap Pertumbuhan dan Hasil Tanaman Jagung (Zea mays). Jurnal Eugenia No3: 1-7 hal. 